\title{
BENDERA DI HIZBUT TAHRIR INDONESIA DAERAH ISTIMEWA YOGYAKARTA (KAJIAN KONTEKS SEJARAH, KONTEKS BUDAYA, DAN ESTETIKA SEMIOTIS)
}

\author{
Deni Junaedi \\ Fakultas Seni Rupa Institut Seni Indonesia Yogyakarta \\ Email: denilonghistory@gmail.com
}

\begin{abstract}
This paper discusses on flags used by Hizb ut-Tahrir Indonesia Yogyakarta (HTI DIY). This organization uses two types of flag: liwa and rayah. The color of the liwa is white and the color of the rayah is black. Upon both the profession of faith (shahada) is written in Arabic Calligraphy. Historically speaking, the Prophet Muhammad used the liwa and the rayah. Politically speaking, both flags are intended for use as the flag of the nwe caliphate to which HizbI ut-Tahrir (HT) aspires. HTI DIY confirms that liwa and rayah are not their flags butflags of Islam. The semiotic aesthetics study of the flags includes the study of aesthetic object, aesthetic values, and aesthetics experience. As aesthetic objects, the liwa and rayah show varieties. Aesthetic values of those flags consist of a symbolic value, one which refers to Islam and the Caliphate; iconic value, i.e.the imitation of the Prophet Muhammad's flags; and indexical value indicating the activity of the HTI DIY. Aesthetic experiences of the flags experienced by the HTI DIY activists are in the form of the emotional effects.
\end{abstract}

Keywords: Liwa and rayah, Hizb ut-Tahrir Indonesia Yogyakarta, semiotic aesthetics, historical context, cultural context.

\begin{abstract}
ABSTRAK
Penelitian ini mengkaji bendera yang digunakan Hizbut Tahrir Indonesia Daerah Istimewa Yogyakarta (HTI DIY). Organisasi ini menggunakan dua jenis bendera, liwa, dan rayah. Liwa berwarna putih dan rayah berwarna hitam, keduanya bertuliskan kaligrafi Arab berlafaz kalimat sahadat. Dalam konteks sejarah terlihat bahwa liwa dan rayah pernah digunakan oleh Nabi Muhammad. Pada konteks budaya terungkap bahwa liwa dan rayah disiapkan sebagai bendera negara Khilafah yang dicita-citakan oleh Hizbut Tahrir (HT). HTI DIY menegaskan bahwa liwa dan rayah bukan benderanya, tetapi bendera Islam. Analisis estetika semiotis meliputi pembahasan tentang objek estetis, nilai estetis, dan pengalaman estetis. Sebagai objek estetis, bentuk liwa dan rayah di HTI DIY memperlihatkan keragaman visual. Nilai estetis yang terkandung di dalamnya terbagi dalam: nilai simbolis, yaitu mengacu pada Islam dan Khilafah; nilai ikonis, yaitu peniruan terhadap bendera Nabi Muhammad; dan nilai indeksikal, menunjukkan keberadaan HTI DIY. Pengalaman estetis yang dialami aktivis HTI DIY, ketika melihat penggunaan bendera itu, berupa efek emosional yang berujud rasa haru atau emioti.
\end{abstract}

Kata Kunci: Liwa dan rayah, Hizbut Tahrir Indonesia Daerah Istimewa Yogyakarta, estetika semiotic, konteks sejarah, konteks budaya. 


\section{PENGANTAR}

Hizbut Tahrir Indonesia Daerah Istimewa Yogyakarta (HTI DIY) merupakan organisasi Islam kontroversial. HTI DIY adalah bagian dari Hizbut Tahrir (HT) yang didirikan oleh Taqiyuddin an-Nabhani di Yerusalem Palestina pada tahun 1953 (Esposito, 2001: 125). Organisasi ini bertujuan untuk mengembalikan kejayaan Islam melalui penegakan negara Khilafah yang menyatukan seluruh dunia(HizbutTahrir, 2009:3). Menurut Muhsin bahwa HT berkembang di lebih dari 70 negara, antara lain yaitu Amerika Serikat, Inggris, Australia, Yaman, Tunisia, Malaysia, dan Indonesia (Amhar, 2010: 9-11). Parpol yang tidak terlibat di parlemen itu sampai ke Indonesia, di kota Bogor, pada tahun 1982. HT di wilayah Indonesia disebut Hizbut Tahrir Indonesia (HTI). Konsep HT masuk ke DIY pada tahun 1988, kepengurusannya secara resmi dibentuk pada tahun 1992 (Muhsin, 2007: 117-123).

Secara harfiah, Hizbut Tahrir bermakna 'partai pembebasan'. Dalam bahasa Arab, hizb berarti 'partai' dan at-tahrir berarti 'pembebasan'. Partai ini mendeklarasikan bahwa ideologinya adalah Islam (Esposito, 2001: 125-126).

Saat mengelar kegiatan terbuka, HTI DIY hampir selalu mengibarkan dua jenis bendera, yaitu liwa dan rayah. Liwa adalah bendera berwarna dasar putih dan bertuliskan kalimat sahadat berwarna hitam seperti gambar berikut ini.

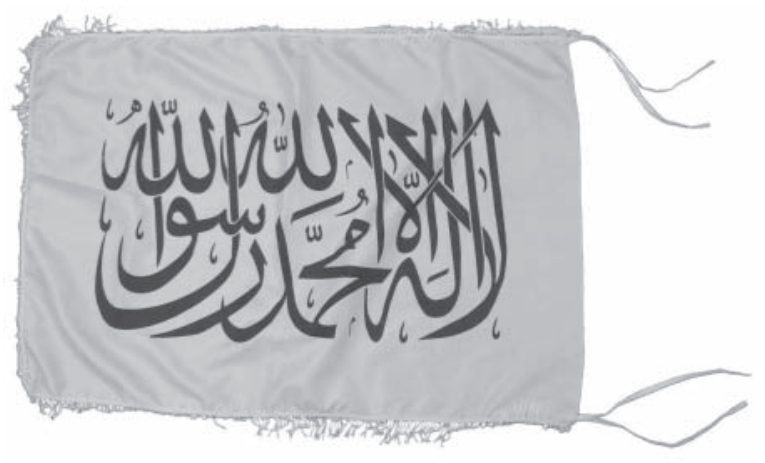

Gambar 1

Liwa berwarna dasar putih dengan kalimat sahadat berwarna hitam

(Foto: Deni Junaedi, 2011)
Kalimat tersebut menggunakan bahasa dan kaligrafi Arab. Lafaz sahadat berbunyi laa ilaaha illaa Allah Muhammad Rasul Allah yang berarti 'tidak ada Tuhan selain Allah Muhammad rasul Allah'. Kebalikannya, rayah memiliki warna dasar hitam dengan kalimat sahadat berwarna putih seperti gambar berikut ini.

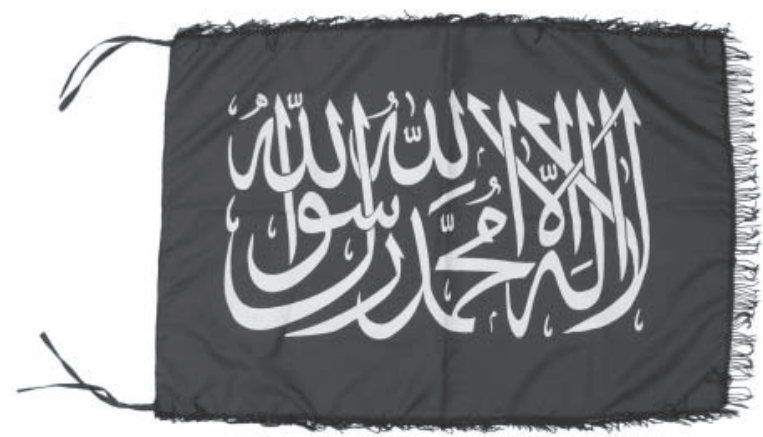

Gambar 2

Rayah berwarna dasar hitam dengan kalimat sahadat berwarna putih (Foto: Deni Junaedi, 2011

Tulisan ini merupakan upaya pemahaman (verstehen) terhadap budaya visual di HTI DIY, yaitu pada penggunaan bendera tersebut. Rumusan masalah yang diajukan adalah: pertama, mengapa liwa dan rayah digunakan oleh HTI DIY?; kedua, bagaimana konteks sejarah bendera tersebut?; ketiga, bagaimana keberadaan bendera itu dalam konteks budaya HTI DIY?; dan keempat, bagaimana estetika semiotis bendera tersebut?

Bentuk maupun penggunaan liwa dan rayah telah diteliti oleh Abdullah bin Muhammad bin Sa'd Al-Hujaili (2002) dalam Al-'Alamu Nabawiy as-Syarif. Ia menggunakan pendekatan historis untuk membahas bendera yang digunakan pada masa Jahiliyah hingga Abasiyah; penekanannya diberikan pada liwa dan rayah yang digunakan Nabi Muhammad. Sumber data yang digunakan adalah hadis Nabi dan catatan sejarah. Pustaka lain yang membahas liwa adalah tulisan Gabriella Elgenius (2007: 17-18), yaitu pada salah satu subbab "The Origin of European National Flags" dalam buku Flag, Nation, Symbolism in Europe and America. Elgenius menyatakan, bangsa Arab menghubungkan warna bendera 
dengan pemimpin sebelumnya; ini berbeda dengan bangsa Cina yang mengidentifikasi setiap warna bendera dengan konsep filsafat atau agama. Akan tetapi, kedua kepustakaan tersebut tidak menyinggung penggunaannya liwa dan rayah oleh HT, apalagi HTI DIY. Dengan demikian, tulisan Al-Hujaili maupun Elgenius berbeda dengan penelitian ini.

Penelitian tentang HTI DIY dikerjakan oleh Illya Muhsin (2007) dalam tesis "Gerakan Penegakan Syariah Islam: Studi tentang Gerakan Sosial Hizbut Tahrir Indonesia di DIY". Penelitiannya menggunakan metode kualitatif dengan pendekatan etnografis. Ulasan Muhsin sama sekali tidak menyinggung liwa dan rayah.

Studi tentang bendera disebut veksillologi (vexillology). Dalam veksillologi, warna dasar bendera disebut ground. Konfigurasi gambar atau tulisan adalah charge. Material tambahan yang digunakan untuk mendekorasi bendera ialah bunting. Ratio adalah perbandingan proporsi antara sisi tinggi dibanding sisi panjang. Displai (display) merupakan cara pemasangan bendera. (Fault, 2007: 1; Roberts, 2008: 7; Smith, 1984: 348-351).

Charge bendera yang digunakan HTI DIY berupa kaligrafi Arab. Dalam bahasa Arab, kaligrafi disebut khat yang berarti 'garis' atau 'tulisan' dan secara istilah berarti 'tulisan yang indah' (AR., 2005: 45). Di antara berbagai khat Arab, terdapat beberapa gaya yang paling menonjol, yaitu naskhi, sulus, diwani, diwani jali, farisi, rigah, dan kufi (AR., 2007: passim).

Kajian konteks sejarah menganalisis liwa dan rayah yang digunakan HTI DIY dalam konteks waktu. Tulisan ini menggunakan model sinkronis dalam pencatatan sejarah. Model sinkronis lebih mengutamakan deskripsi yang meluas dalam ruang tanpa terlalu banyak menyinggung dimensi waktu (Kuntowijoyo, 2003: 43).

Kajian konteks budaya menganalisis liwa dan rayah dalam budaya HTI DIY. J.J. Honingman mengelompokkan unsur budaya menjadi tiga, yaitu sistem budaya, aktivitas, dan artefak. Sistem budaya terdiri dari gagasan, pikiran, konsep, nilai, norma, pandangan, atau sejenisnya yang bersifat abstrak; aktivitas merupakan tingkah laku berpola para pelaku budaya; dan artefak berupa benda ciptaan manusia (Soekiman, 2000: 40-41).

Kajian estetika semiotis merupakan analisis terhadap liwa dan rayah yang digunakan HTI DIY dalam perspektif estetika yang ditempatkan dalam kerangka semiotika. Analisis estetika melalui metodologi semiotika mendefinisikan estetika sebagai "kajian tentang proses estetis". Proses estetis juga disebut estesis. Istilah ini berkorelasi dengan kata semiosis dalam terminologi semiotika. (Katya Mandoki, 2007: Xi dan 101-102) disebut semio-aesthetics. Untuk hal yang sama bahwa Winfried Nöth dalam metodologi semiotika menggunakan istilah semiotic aesthetics dan semiosis merupakan proses penandaan atau proses penerimaan suatu tanda oleh interpreter (Winfried Nöth, 1990: 42 dan 421). Semiotika adalah studi tentang tanda dan cara kerja tanda (Fiske, 2011: 60).

Penelitian ini memanfaatkan model semiosis Charles Sander Peirce untuk diterapkan dalam estesis. Semiosis Peircean bersifat triadik. Sudut segitiganya terdiri dari representamen, object, dan interpertant. Menurut Peirce (1955: 99), representamen adalah sesuatu yang berada bagi seseorang untuk sesuatu yang lain dalam berbagai cara atau kapasitas; bagian ini merupakan aspek material suatu tanda. Object, berbeda dengan pengertian sehari-hari adalah sesuatu yang diacu oleh representament. Interpretant merupakan hal yang muncul pada benak seseorang karena dibangkitkan oleh representament.

Dalam penelitian ini, segitiga semiosis Peirce diadopsi menjadi segitiga estesis. Sudut representamen ditempati "objek estetis"; object diubah menjadi "nilai estetis", dan interpretant diganti dengan "pengalaman estetis". Objek estetis, nilai estetis, maupun pengalaman estetis merupakan ranah pembahasan estetika yang penting (Eaton, 2010: xiii). Nilai estetis menempati puncak segitiga, hal ini untuk menunjukkan bahwa nilai bersifat objektif dan subjektif sekaligus. 
Objek estetis adalah apapun yang dapat merangsang kemunculan pengalaman estetis (Thomas Munro,1970: 22). Nilai estetis adalah nilai yang dimiliki objek terkait dengan kapasitasnya untuk membangkitkan kesenangan, yang muncul dari ciri objek yang secara tradisional dianggap berharga untuk diperhatikan dan direfleksikan (Marcia Muelder Eaton, 2010:181). Adapun pengalaman estetis adalah pengalaman tentang tanda intrinsik sesuatu yang secara tradisional dianggap berharga untuk diperhatikan dan direfleksikan. Secara ringkas, kerangka teoretik ini dapat dilihat pada skema di bawah ini.

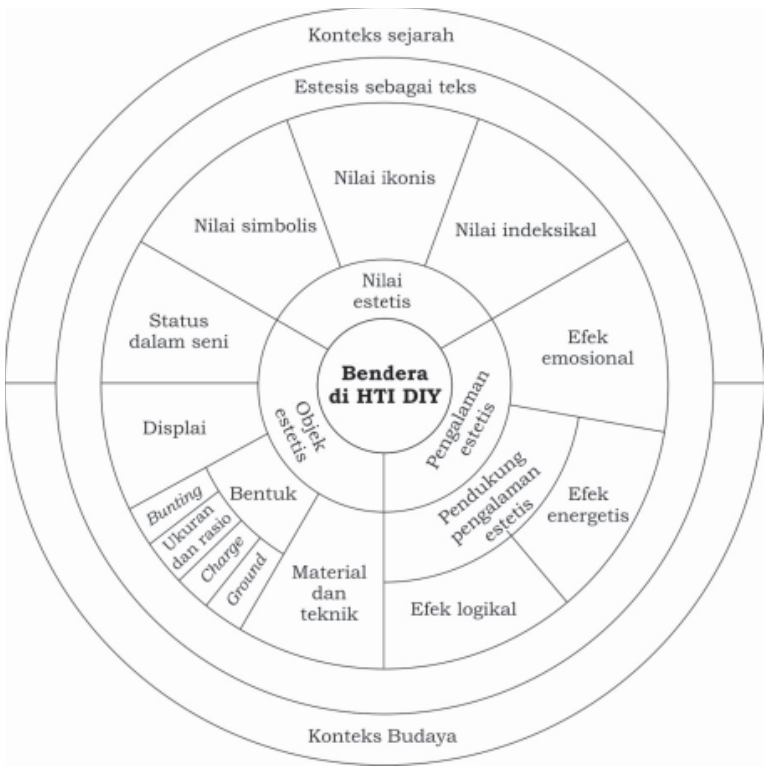

Gambar 3

Skema teori

(Dibuat oleh: Deni Junaedi, 2011)

Observasi dilakukan pada kegiatan HTI DIY dengan penekanan pada penggunaan liwa dan rayah. Kegiatan tersebut meliputi masirah (demonstrasi), konferensi, seminar, diskusi, pawai, bantuan bencana alam, syawalan, kajian kitab HT, halqah (lingkar studi), dan pertemuan internal sabab (aktivis) HTI DIY.

Wawancara dilakukan terhadap: Ismail Yusanto, Juru Bicara HTI; Rosyid Supriyadi, Ketua DPD I HTI DIY; Dhuha Ghufron, Penanggungjawab (Mas'ul) HTI DIY; Aruman, anggota HTI DIY yang juga kaligrafer (khattat) liwa dan rayah; Andika
Dwijatmiko, anggota HTI DIY dan desainer logo HTI maupun desainer visual kegiatan HTI; Eko Pujiyanto dan Nunuk Dwi Hariyani, produsen liwa dan rayah dari Ahsanta Design and Product; dan beberapa anggota maupun pelajar HTI DIY.

Studi dokumen dilakukan terhadap bendera, foto, video, dan terbitan resmi HT, HTI, atau HTI DIY. Terbitan HT berupa buku materi halqoh, majalah al-Wa'ie, tabloit Media Umat, buletin al-Islam, selebaran, spanduk, banner, poster, maupun website HT.

\section{PEMBAHASAN}

Pembahasan penelitian terbagi dalam tiga subbab, yaitu liwa dan rayah dalam konteks sejarah, liwa dan rayah dalam konteks budaya HTI DIY, dan estetika semiotis liwa dan rayah di HTI DIY.

\section{Liwa dan Rayah dalam Konteks Sejarah}

Setelah Negara Islam terbentuk di Madinah pada tahun 622, Nabi Muhammad memerintahkan penggunaan liwa (bendera) dan rayah (panji). Liwa berwarna dasar putih, sedangkan rayah menggunakan ground hitam. Hal ini sesuai dengan hadis yang disampaikan Ibnu Abas, "Rayah Rasulullah saw berwarna hitam, dan liwa-nya berwarna putih." Hadis serupa juga diriwayatkan oleh Aisyah, Abu Hurairah, Abdullah bin Buraidah, maupun Rasyid bin Saad (AlHujaili, 2002: 44-50).

Charge liwa yang digunakan Nabi Muhammad berupa kalimat sahadat. Hal ini terekam dalam hadis yang disampaikan oleh Abu Hurairah dan Ibnu Abbas, "Liwa Nabi saw tertulis laa ilaaha illaa Allah Muhammad Rasul Allah." Mahmud Abbas memperkirakan bahan yang digunakan untuk menulis adalah arang hitam atau jelaga yang dicampur dengan getah pohon (Al-Hujaili, 2002: 65-67).

Umumnya, liwa dan rayah pada zaman Nabi Muhammad digunakan dalam peperangan. Liwa berada di dekat pemimpin tertinggi atau wakilnya, sedangakan rayah digunakan untuk komandan bagian. Dalam bahasa militer modern, Abdul Qadim Zallum (2002: 191) menyatakan, liwa untuk 
menandakan komandan resimen, sedangkan rayah dibawa komandan batalion. Dengan demikian, pada sebuah peperangan hanya terdapat sebuah liwa dan dimungkinkan ada beberapa rayah (Al-Hujaili, 2002: 32-36).

Setelah Nabi Muhammad wafat pada tahun 632, pemerintahan Islam diteruskan sahabatnya. Periode Khulafaur Rasyidin ini tetap menjaga penggunaan panji hitam. Khalid bin Walid diangkat Abu Bakar sebagai panglima perang di Damaskus, membawa rayah, dan mengibarkannya ketika memerangi bani Hanifah dan nabi palsu Musailamah. Demikian juga, saat perang Jamal, Ali membawa panji berwarna hitam (Al-Hujaili, 2001: 121-123; Khalid, 2006: 351).

Selanjutnya, di periode Khilafah Umawiyah hingga Usmaniyah bermunculan berbagai jenis bendera; periode ini sangat panjang, sejaktahun661 hingga saatkeruntuhan Khilafah tahun 1924. Ground yang ada adalah putih, hitam, hijau, dan merah. Adapun charge yang dibubuhkan meliputi kaligrafi Arab baik berupa kalimat sahadat maupun selain lafaz itu; gambar bulan sabit dan bintang atau hanya bulan sabit; pedang, baik pedang Zulfiqar maupun pedang berujung satu; lingkaran yang mengingatkan pada stempel nabi; dan, kendati sedikit, juga gambar mahluk hidup baik manusia atau binatang.

Di periode setelah keruntuhan Khilafah, tipe bendera Barat mempengaruhi bendera negara bangsa (nation state) di negeri Muslim. Secara visual pengaruh itu terdapat pada komposisi bicolor, tricolor, atau tribar. Bicolor adalah pola bendera dua warna baik terkomposisi secara vertikal maupun horisontal. Tricolor terdiri dari tiga warna yang berderet vertikal. Tribar terkomposisi dari tiga warna yang berjajar secara horisontal.

Setelah keruntuhan Khilafah banyak organisasi Islam terbentuk. Di antaranya terdapat beberapa organisasi yang menggunakan liwa dan terutama rayah. Liwa dan rayah yang digunakan organisasi Islam selain HT kerap kali tidak hanya bertuliskan kalimat sahadat, tetapi ditambah gambar pedang. Organisasi Islam yang menggunakan rayah, antara lain Al-Qaeda; Osama bin Laden, pemimpinnya, sering ditampilkan berpidato dengan latar belakang rayah (As-Suri, 2010: 81).

HT adalah salah satu organisasi Islam yang mengibarkan liwa dan rayah. Di belahan bumi manapun, HT mengibarkan bendera yang sama. Hal itu terjadi karena HT menyebarkan pemikirannya melalui buku yang sama. Di Indonesia, liwa dan rayah mulai dikibarkan secara terbuka sejak tahun 2000 dalam acara Konferensi Khilafah Islamiyah. Dengan demikian, HTI mesti menunggu pengibarannya selama delapan belas tahun sejak masuk ke Indonesia yang saat itu masih berada di bawah pemerintahan Orde Baru. Sebagai bagian dari HTI, HTI DIY terlibat dalam Konferensi Khilafah Islamiyah. Secara ringkas, posisi liwa dan rayah dalam konteks sejarah dapat dilihat dalam skema di gambar 4 di bawah ini.

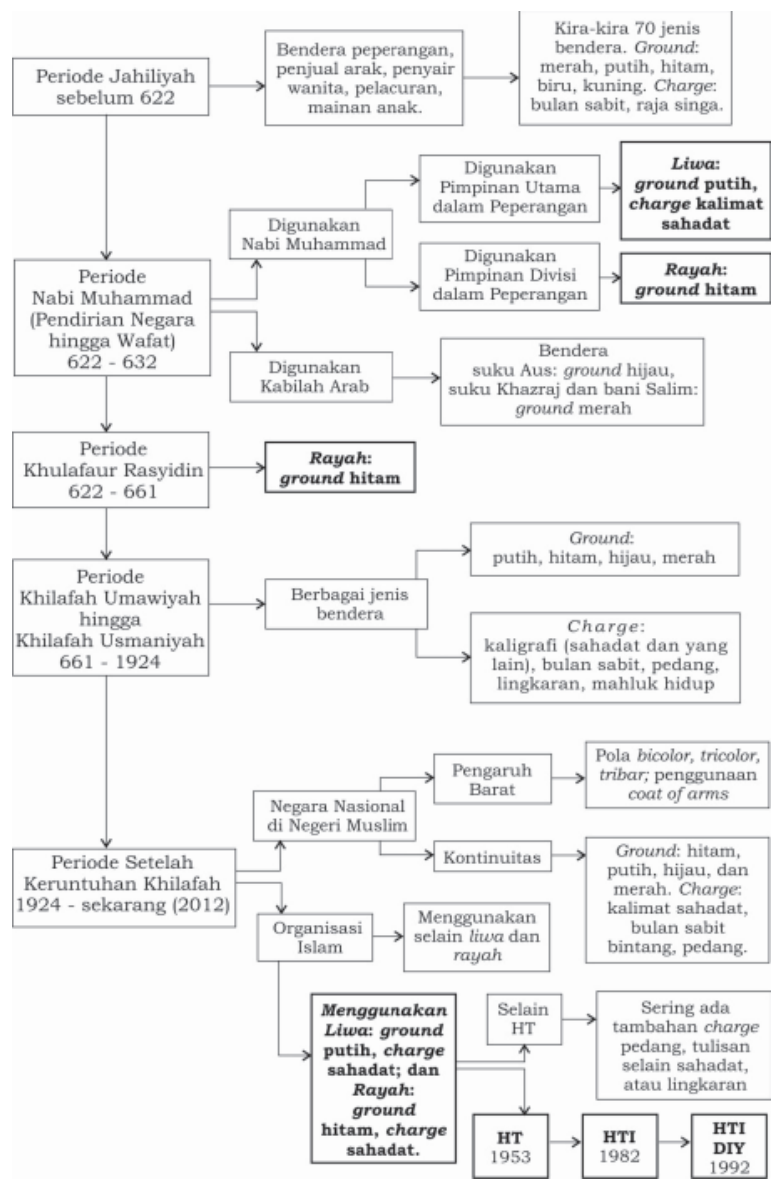

Gambar 4.

Skema posisi liwa dan rayah dalam konteks sejarah

(Dibuat oleh: Deni Junaedi, 2012) 


\section{Liwa dan Rayah dalam Konteks Budaya HTI DIY}

Liwa dan rayah dalam konteks budaya HTI DIY dapat dilihat dalam tiga ranah, yaitu sistem budaya, aktivitas, dan artefak. Sistem budaya terkait dengan pemikiran HT yang dianut HTI DIY terkait dengan bendera tersebut; aktivitas merupakan kegiatan yang dilakukan HTI DIY terkait dengan liwa dan rayah; sedangkan artefak adalah liwa dan rayah itu sendiri maupun benda yang berhubungan dengan bendera itu.

Pada tataran sistem budaya, landasan utama HTI DIY adalah bangunan keimanan yang diperoleh dengan akal (dalil aqli) maupun didasarkan pada kutipan al-Quran dan hadis mutawatir (dalil naqli). Keimanan berdasarkan akal meliputi keimanan pada keberadaan Pencipta, kemukjizatan alQuran, dan kenabian Muhammad; keimanan berdasarkan kutipan (naqli) diterapkan pada hal gaib lainnya. Persoalan ini dibahas dalam buku resmi HT yang berjudul Nizham al-Islam (peraturan hidup dalam Islam) (An-Nabhani, 2001b: 4-13).

Cara untuk membuktikan keberadaan Pencipta adalah dengan memperhatikan alam, kehidupan, dan manusia. Ketiga hal itu memiliki sifat terbatas dan tergantung dengan yang lain. Sesuatu yang bersifat batas dan tergantung dengan yang lain membutuhkan hal yang tidak terbatas dan tidak tergantung dengan yang lain, yaitu Pencipta (al-Khaliq). Dengan demikian, keberadaan Pencipta adalah keniscayaan (wajibul wujud) karena tidak terbatas, Pencipta tidak diciptakan oleh pencipta lain atau menciptakan dirinya sendiri, tetapi bersifat azali atau tidak berawal dan tidak berakhir. Berdasarkan naluri beragama (yang perwujudannya dapat berupa pengagungan atas sesuatu), maka manusia akan berusaha beribadah kepada Pencipta. Untuk melakukannya, manusia memerlukan pedoman yang berasal dari Pencipta.

Keterangan ulama lain, an-Nabhani menyatakan bahwa al-Quran merupakan pedoman yang berasal dari Pencipta. Hal ini dibuktikan dengan ayat yang berisi tantangan bagi orang yang meragukannya. Para peragu diminta untuk membuat surat yang semisal dengan al-Quran. Tantangan semacam itu, antara lain terdapat dalam surat al-Baqarah ayat 23, "Dan jika kamu dalam keraguan tentang al-Quran yang Kami wahyukan kepada hamba Kami (Muhammad), buatlah satu surat yang semisal dengannya, dan ajaklah penolong-penolongmu selain Allah, jika kamu orang-orang yang benar." Tantangan tersebut tidak terjawab hingga kini. Ayat selanjutnya mempertegas, "Maka jika kamu tidak dapat membuat, dan pasti kamu tidak akan dapat membuat, peliharalah dirimu dari neraka yang bahan bakarnya berupa manusia dan batu, yang disediakan bagi orang-orang kafir." Dengan demikian, HT menegaskan, kemukjizatan bahwa alQuran dari Pencipta tidak terbantahkan. Muhammad yang membawa al-Quran, sebagai mukjizatnya, mengindikasikan kedudukannya sebagai nabi.

Selanjutnya, keimanan tersebut diimplementasikan dalam segala perilaku. Peraturan Islam menurut HT mengatur tiga aspek, yaitu hubungan manusia dengan Pencipta, dengan dirinya sendiri, dan dengan sesamanya. Aspek pertama meliputi perkara akidah dan ibadah; aspek kedua terkait dengan akhlak, makanan, dan pakaian; aspek terakhir termasuk dalam pengaturan negara (An-Nabhani, 2001b: 79). Negara dalam sistem Islam berbentuk Khilafah. Pemerintahan yang dipimpin seorang Khalifah ini menyatukan seluruh dunia berdasarkan syariah Islam. Penegakan Khilafah menjadi titik penekanan perjuangan HT. Walaupun bertujuan mendirikan negara, dalam perjuangannya HT melarang penggunaan senjata atau perlawanan fisik (Redaksi Al-Wa'ie, 2011: 20). Metode yang digunakan HT untuk mendirikan Khilafah terdiri dari tiga tahap, yaitu pembentukan kutlah, tafaul maal ummah, dan thalabun nushrah. Pembentukan kutlah adalah tahap pembentukan kelompok, dalam hal ini merupakan pembentukan partai politik. Tafaul maal ummah merupakan fase interaksi HT terhadap umat atau masyarakat. Thalabun nushrah adalah babak pencarian dukungan 
dari pemiliki kekuatan (militer) agar mau menyerahkan kekuasaan. (An-Nabhani, 2001a: 30-55). Cara ini mencontoh Nabi Muhammad ketika melakukan penegakan negara Islam di Madinah (Al-Jawi, 2011: 17-21).

Berdasarkan telaah hadis, HT menyimpulkan bahwa negara Khilafah harus menggunakan liwa (bendera) dan rayah (panji). Bahkan, HT mencantumkan penggunaan liwa dan rayah dalam Rancangan Undang-Undang Dasar (Dustur) Negara Islam. Bab Angkatan Bersenjata Pasal 60 menyebutkan, "Dalam angkatan bersenjata ditentukan keberadaan liwa dan rayah" (An-Nabhani, 2001b: 102).

Selanjutnya, dalam tataran aktivitas, maka liwa dan rayah dipakai untuk kegiatan HTI DIY yang bersifat terbuka, seperti masirah (unjuk rasa), konferensi, seminar, diskusi, maupun bantuan bencana alam. Adapaun kegitan yang bersifat internal tidak memakainya, misalnya, halqoh rutin atau rapat sabab HTI DIY.

Pada tataran artefak, maka liwa dan rayah merupakan benda penting di HTI DIY; hal ini terindikasi dari penggunaannya dalam berbagai kegiatan. Selain itu, liwa dan rayah sering menjadi sumber inspirasi untuk membuat desain visual, misalnya, untuk logo HTI bahwa artefak di HTI DIY yang terinspirasi oleh liwa maupun rayah dapat dipandang sebagai derivasi dari bendera di bawah ini.

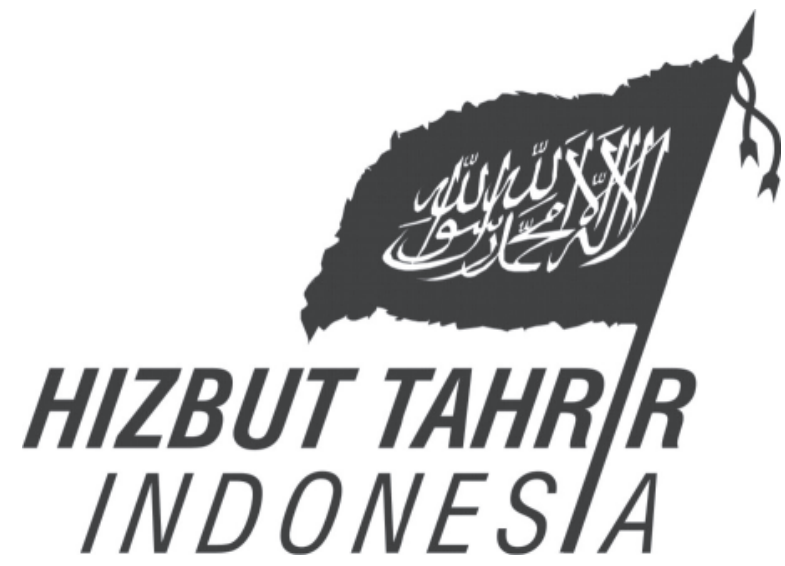

Gambar 5. Logo HTI

(Desain oleh: Andika Dwijatmiko)
Secara ringkas, posisi liwa dan rayah dalam konteks budaya HTI DIY dapat dilihat di skema pada gambar 6 .

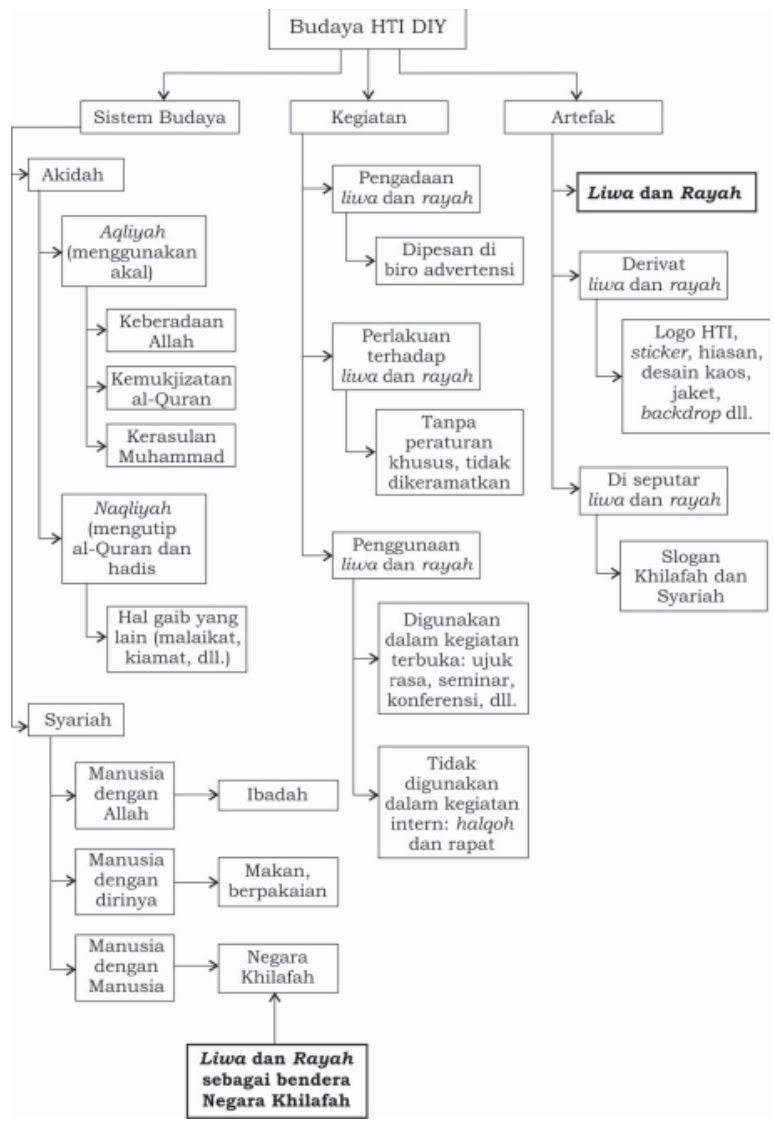

Gambar 6

Skema posisi liwa dan rayah dalam konteks budaya HTI DIY

(Dibuat oleh: Deni Junaedi, 2012)

\section{Estetika Semiotis Liwa dan Rayah di HTI DIY}

Liwa dan rayah dapat dipandang sebagai objek estetis karena mampu membangkitkan pengalaman estetis. Objek estetis yang berupa karya seni rupa, maka objek tersebut memiliki bentuk yang terbuat dari material tertentu dan dikerjakan dengan teknik tertentu. Kebanyakan bendera di HTI DIY terbuat dari bahan kain dengan teknik sablon. Selain itu, sebagian bendera juga dibuat dari kertas dengan teknik fotokopi dan vinil dengan teknik cetak digital. 
Secara visual, liwa memiliki ground putih dengan charge kalimat sahadat berwarna hitam. Sebaliknya, rayah memiliki ground hitam dengan kalimat sahadat berwarna putih. Sebagian bendera di HTI DIY menggunakan bunting atau hiasan berupa rumbai.

Semua bendera yang digunakan HTI DIY menggunakan khat sulus, tetapi komposisinya beragam, misalnya terdapat yang berkomposisi segiempat (gambar 1), lingkaran (gambar. 7), atau segiempat dengan penekanan lafaz Allah di bagian tengah atas (gambar. 8). Keragaman juga terjadi pada ukuran, rasio, maupun displai.

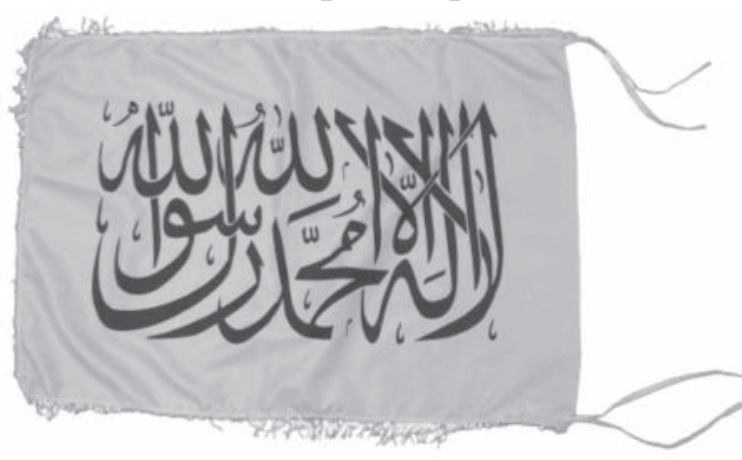

Gambar 1

Liwa berwarna dasar putih dengan kalimat sahadat

berwarna hitam

(Foto: Deni Junaedi, 2011)

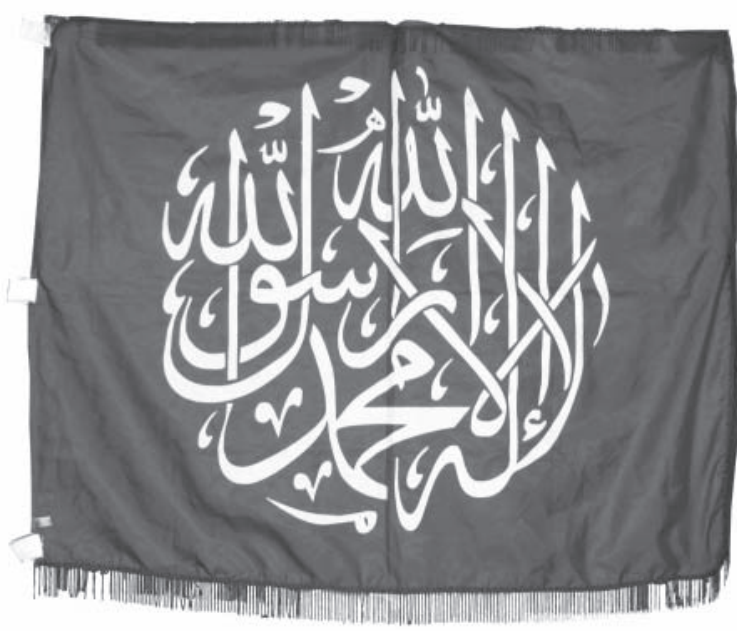

Gambar 7

Komposisi khat berbentuk lingkaran (Foto: Deni Junaedi, 2011)

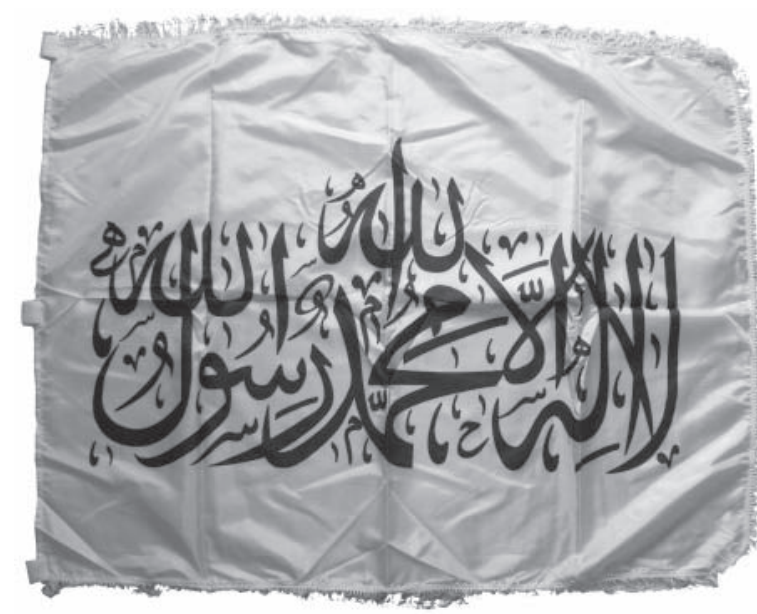

Gambar 8

Komposisi segiempat dengan penekanan pada lafaz Allah di bagian tengah atas

(Foto: Deni Junaedi, 2011)

Sebagai objek estetis, liwa dan rayah memiliki nilai estetis. Nilai estetis yang terkandung pada bendera itu meliputi nilai simbolis, nilai ikonis, dan nilai indeksikal. Nilai simbolik merupakan kaitan antara bendera tersebut dengan Islam dan konsep penegakan Khilafah. Hubungan liwa dan rayah dengan Islam dapat dilihat pada charge bendera tersebut, yaitu kalimat sahadat. Pernyataan laa ilaaha illa Allah Muhammad Rasul Allah hanya ada di dalam Islam, dan menjadi syarat mutlak yang harus diucapkan seseorang ketika menyatakan keislamannya. Kalimat tersebut juga selalu dibaca saat orang Muslim melaksanakan sholat. Keterkaitan liwa dan rayah dengan Islam, dalam konteks HTI DIY, ditegaskan melalui pernyataan Rasyid Supriyadi, Ketua DPD HTI DIY bahwa bendera tersebut bukanlah bendera HT atau organisasi tertentu, tetapi bendera Islam. Selain itu, secara terbuka dalam aksi "Mengutuk Rencana Pembakaran al-Quran" di depan Kantor Pos Pusat Yogyakarta tanggal 29 Agustus 2010, orator aksi menyerukan, "Kibarkan liwa dan rayah! Bendera itu adalah bendera Rasulullah, bendera umat Islam, bukan bendera organisasi manapun."

Liwa dan rayah di HTI DIY juga menjadi simbol penegakan Khilafah. Dengan kata lain, bendera itu memiliki kapasitas untuk 
dikaitkan dengan ide penegakan Khilafah. Pada beberapa buku resmi HT keberadaan liwa dan rayah terkait erat dengan negara Khilafah (An-Nabhani: 2009, 310; AnNabhani, 2001b: 102; An-Nabhani, 2003: 310314; Hizbut Tahrir, 2005: 169-172).

Nilai ikonis pada liwa dan rayah di HTI DIY mengindikasikan bendera tersebut memiliki kesamaan dengan acuannya. Dalam hal ini, acuan tersebut adalah bendera yang digunakan Nabi Muhammad. Dengan kata lain, liwa dan rayah di HTI DIY bernilai ikonis karena meniru bendera Rasulullah; warna putih maupun hitam sama sekali tidak memiliki makna tertentu sebagaimana kebanyakan warna bendera, seperti putih berarti suci.

Liwa dan rayah memiliki nilai indeksikal. Ini berarti pengibaran liwa dan rayah di DIY mengindikasikan keberadaan kegiatan HTI DIY. Contohnya adalah pemasangan liwa dan rayah di jalan lingkar Yogyakarta tanggal 19 Juni 2011 yang mengindikasikan kegiatan Konferensi Rajab (Konjab) 1432 $\mathrm{H}$ yang diselenggarakan HTI DIY. Akan tetapi, terdapat kemungkinan, meskipun kecil bahwa pemakaian liwa dan rayah di DIY tidak mengindikasikan keberadaan kegiatan HTI DIY. Hal ini mengingat bendera tersebut kadang juga digunakan oleh organisasi Islam lainnya, misalnya, oleh Majelis Mujahidin Indonesia (MMI), meskipun rayah di MMI ditambah dengan gambar pedang.

Pengalaman estetis yang dirasakan aktivis atau sabab HTI DIY ketika melihat penggunaan liwa dan rayah berupa efek emosional. Namun demikian, bendera itu tidak hanya menyebabkan efek emosional, tetapi juga efek energetis dan efek logikal. Efek energetis, meskipun bukan bentuk pengalaman estetis merupakan aspek penambah pengalaman estetis dan juga aspek yang terlihat dari pengalaman estetis. Demikian pula, pengalaman estetis terkait dan terjadi secara bersama dengan efek logikal.

Efek emosional merupakan perasaan yang timbul pada sabab HTI DIY saat menyaksikan pengibaran liwa dan rayah. Efek tersebut berupa perasaan haru. Keterharuan atau yang terkait dengannya seperti rasa ingin menangis diakui oleh sabab HTI DIY. Rasyid Supriyadi adalah Ketua DPD I HTI DIY merasa terharu, setelah menyaksikan pengibaran liwa dan rayah pada acara Konjab $1432 \mathrm{H}$ tanggal 19 Juni 2011. Pentas pengibaran liwa dan rayah yang berlangsung di Jogja Expo Center (JEC) itu juga menimbulkan perasaan haru bagi seorang daris (pelajar) HTI DIY, bahkan mengaku hampir tidak dapat menahan tangis, "Saya tidak berani menoleh ke sebelah, karena air mataku akan jatuh." Demikian pula, pernyataan anggota HTI DIY yang bertugas menjawab pertanyaan wartawan pada acara itu menggambarkan perasaan haru yang dirasakan pada sebagian besar sabab HTI DIY, "Banyak peserta Konjab yang akan menangis saat menyaksikan pengibaran liwa dan rayah."

Keterharuan yang dirasakan sabab HTI DIY merupakan campuran antara perasaan senang, bangga, semangat, kagum, terpesona, dan sekaligus merasa berhadapan dengan sesuatu yang besar. Perasaan seperti itu, meskipun tidak sepenuhnya, merupakan bentuk kondisi sublim (sublime). Sublim pada abad ke-18 merupakan pengalaman tentang astonishment. Astonishment adalah gerakan jiwa yang tertahan dan dengan sedikit unsur rasa mencekam (horror) (Edmund Burke, 1764: 95). Baik Burke maupan Kant memberikan contoh sublim dengan pengalaman ketika berhadapan dengan keagungan alam, misalnya, gunung yang tinggi atau padang pasir yang luas (Crawford, 2005: 58).

Konsep Khilafah sebagai negara superpower yang dicita-citakan HT, dan liwa dan rayah yang menjadi simbol penegakan Khilafah, menjadikan bendera itu berefek bagi sabab HTI DIY sebagaimana berhadapan dengan sesuatu yang besar. Keterpesonaan pada sesuatu yang besar ini, sedikit atau banyak, dapat dibandingkan dengan ketika seseorang menghadapi alam yang secara fisik lebih besar dari dirinya. Dengan demikian, kondisi sublim dapat digunakan untuk menamai pengalaman estetis yang dirasakan sabab HTI DIY ketika melihat penggunaan liwa dan rayah.

Pengalaman estetis yang dirasakan sabab HTI DIY itu kadang diperkuat dengan 
efek energetis. Efek yang bukan termasuk pengalaman estetis ini berupa acungan kepalan tangan dan teriakan takbir. Pada saat yang bersamaan, pengibaran bendera itu menimbulkan efek logikal, yaitu pemikiran yang mengaitkan liwa dan rayah dengan Islam dan Khilafah. Efek ini juga bukan termasuk pengalaman estetis, tetapi tanpa unsur logikal pengalaman estetis tidak akan muncul.

Proses kemunculan pengalaman estetis yang dibangkitkan oleh objek estetis di bawah pengaruh nilai estetis disebut estesis. Pengalaman estetis yang muncul pada sabab HTI DIY saat mengamati penggunaan liwa dan rayah sebagai objek estetis dipengaruhi oleh nilai estetis yang terkandung pada objek tersebut, yaitu nilai simbolis, nilai ikonis, dan nilai indeksikal. Nilai tersebut terkandung di dalam objek, yaitu liwa dan rayah, dan tertangkap oleh subjek, yaitu sabab HTI DIY. Secara singkat, estesis yang terjadi pada penggunaan liwa dan rayah di HTI DIY dapat dilihat di skema pada gambar 9.

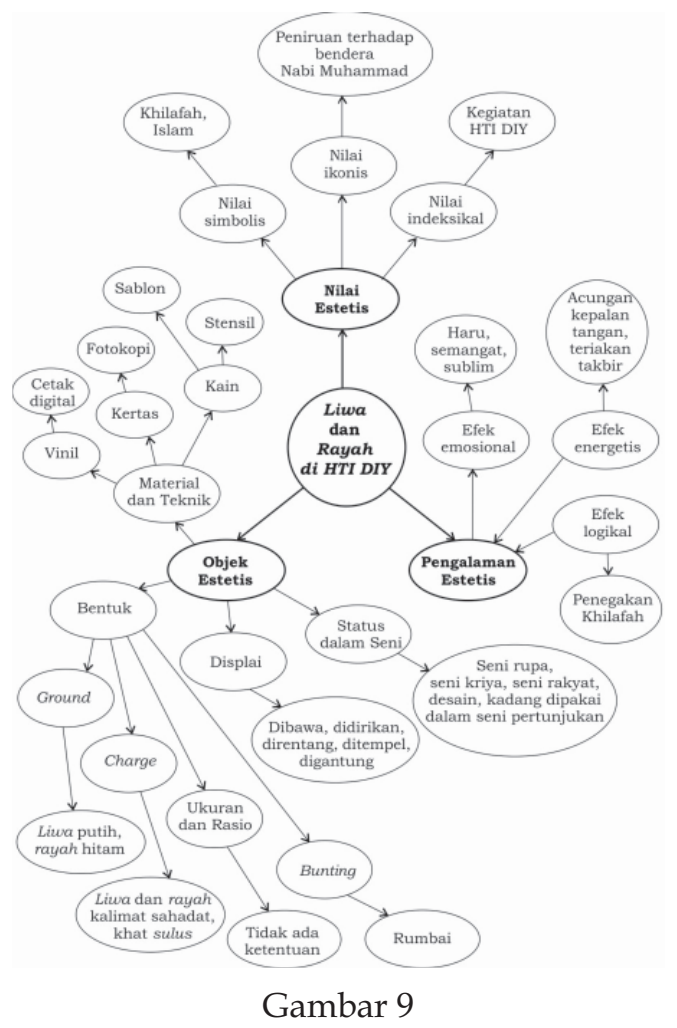

Skema estetika semiotis liwa dan rayah di HTI DIY

(Dibuat oleh: Deni Junaedi, 2012)

\section{SIMPULAN}

Liwa dan rayah digunakan HTI DIY sebagai upaya peniruan terhadap bendera Nabi Muhammad dan bendera tersebut dipersiapkan sebagai bendera negara Khilafah yang dicita-citakan HT; liwa dan rayah tidak dianggap sebagai bendera HTI DIY,HT, maupun organisasi manapun, tetapi bendera milik umat Islam. Dalam konteks sejarah, penggunaan bendera di HTI DIY merupakan fenomena pengulangan sejarah sebagaimana penggunaan bendera pada periode Nabi Muhammad.. Dalam konteks budaya, liwa dan rayah merupakan artefak penting di HTI DIY karena hampir selalu digunakan dalam kegiatannya yang bersifat terbuka; penggunaan bendera itu didasari sistem budaya yang dipelajari sabab HTI DIY. Dalam estetika semiotis, proses estetis atau estesis terjadi karena liwa dan rayah sebagai objek estetis, yaitu membangkitkan pengalaman estetis pada sabab HTI DIY. Pengalaman itu muncul karena sabab HTI DIY mampu menangkap nilai estetis yang terkandung dalam bendera itu dan kemampuan penangkapan nilai ini tidak terlepas dari pembelajaran yang diterima aktivis HTI DIY.

\section{DAFTAR PUSTAKA}

Al-Hujaili, Abdullah bin Muhammad bi Sa'd, 2002, Al-'Alamu Nabawiy asSyarif wa Tatbiqatihi al-Qadimatu wa al-Ma'ashiratu. Madinah alMunawarah: Maktabat al-'Ulum wa al-Khikam.

Al-Jawi, S., 2011, “Thalabul-Nushrah: Kunci Perubahan Haqiqi", dalam majalah Al-Wa'ie. Jakarta: HTI, no. 129, tahun XI, 1-31 Mei.

Amhar, F., 2010, "Peta Global Perjuangan Menegakkan Khilafah", dalam majalah Al-Wa'ie. Jakarta: HTI, No. 119, Tahun X,1-31 Juli.

An-Nabhani, Taqiyuddin, 2001a, At-Takattul al-Hizbiy. Tanpa kota: Hizbut Tahrir. 
, 2001b, Nizamul al-Islam. Tanpa kota: Hizbut Tahrir.

,2003, Kepribadian Islam, terj. Agung Wijayanto, et al. Jakarta: Hizbut Tahrir Indonesia, cetakan ke-5. 2009, Daulah Islam, Terj. Umar Faruq. Jakarta: HTI Pres, cetakan ke-4.

AR., D. Sirojuddin, 2005, "Kaligrafi" dalam Ensiklopedi Islam. Jakarta: Ichtiar Baru van Hoeve.

, 2007, Koleksi Karya Master Kaligrafi Islam (Naskhi, Sulus, Diwani, Diwani Jali, Farisi, Kufi, Riq'ah). Jakarta: Darul Ulum Press.

As-Suri, Abu Mush'ab, 2010, Perjalanan Gerakan Jihad (1930-2002): Sejarah, Eksperimen, dan Evaluasi, terj. Agus Suwandi. Solo: Jazera.

Burke, Edmund, 1764, A Philosophical Enquiry into the Origin Of Our Ideas of the Sublime and Beautiful. London: R. and J. Dodsley.

Crawford, D. W., 2005, “Kant”, dalam Berys Gault dan Dominic Mclver Lopes, The Routledge Companian to Aesthetics. London dan New York: Routledge.

Eaton, M. M., 2010, Persoalan-persoalan Dasar Estetika, terj. Embun Kenyowati Ekosiwi.Jakarta:SalembaHumanika.

Elgenius, G., 2007, “The Origin of European National Flags", dalam Thomas Hylland Eriksen dan Richard Jenkins, ed., Flag, Nation, Symbolism in Europe and America. New York: Routledge.

Esposito, J. L., ed., 2001, The Oxford Encyclopedia of the Modern Islamic World, volume 2. New York: Oxford University Press.

Fault, M., ed., 2007, "50 Years of Vexillology", dalam jurnal Flagmaster the Journal of the Flag Institute. York, issue 124, Agustus.

Fiske, J., 2011, Cultural and Communication Studies, terj. Yosal Iriantara dan
Idi Subandy Ibrahim. Yogyakarta: Jalasutra.

Hizbut Tahrir, 2005, Ajhizah ad-Daulah alKhilafah. Libanon: Darul Umah, 2005. , 2009, Mengenal Hizbut Tahrir dan Strategi Dakwah Hizbut Tahrir, terj. Abu Afif dan Nur Khalish. Bogor: Pustaka Thariqul Izzah, cetakan ke3.

Khalid, K. M., 2006, Karakteristik Perihidup Enam Puluh Shahabat Rasulullah, terj. Mahyuddun Syaf. Bandung: Diponegoro, cetakan ke-20.

Kuntowijoyo, 2003, Metodologi Sejarah. Yogyakarta: Tiara Wacana, cetakan ke-2.

Mandoki, K., 2007, Everyday Aesthetics: Prosaics, the Play of Culture and Social Identities. Hampshire: Ashgate.

Muhsin, I., 2007, “Gerakan Penegakan Syariah Islam: Studi tentang Gerakan Sosial Hizbut Tahrir Indoensia di DIY". Tesis Program Studi Sosiologi Sekolah Pascasarjana UGM.

Munro, T., 1970, Form and Style in the Arts: an Introduction to Aesthetic Morpology. Cleveland: The Press of Case Western University.

Nöth, W., 1990, Handbook of Semiotics. Bloomington dan Indianapolis: Indiana University Press.

Peirce, C. S., 1955, "Logic as Semiotic: The Theory of Sign", dalam Justus Bucher, ed., Philosophical Writing of Peirce. New York: Dover.

Redaksi Al-Wa'ie, 2011, “Rachmad S. Labib: Hizbut Tahrir Tidak Menggunakan Kekerasan", dalam majalah Al-Wa'ie. Jakarta: HTI, No.18,Tahun XI, 1-30 Juni.

Roberts, D., 2008, Complete Flags of the World. London, New York, Melbourne, Munich, dan Delhi: DK, cetakan ke- 


\section{Deni Junaedi -- Bendera di Hizbut Tahrir Indonesia Daerah Istimewa Yogyakarta}

(Kajian Konteks Sejarah, Konteks Budaya, dan Estetika Semiotis)

7.

Smith, W. 1984, The Encyclopedia Americana International Edition, Volume 11. Connecticut: Grolier Incorporated.
Zallum, A. Q., 2002, Sistem Pemerintahan Islam, terj. M. Maghfur W. Bangil: AlIzzah, cetakan ke-3.

Soekiman, D., 2000, Kebudayaan Indis dan Gaya Hidup Masyarakat Pendukungnya di Jawa (Abad XVIII - Medio Abad XX). Yogyakarta: Bentang Budaya. 